\title{
Ranunculus meristus (Ranunculaceae), a new stoloniferous species from eastern Australia
}

\author{
Barbara G. Briggs and R.O. Makinson
}

\begin{abstract}
Briggs, Barbara G. and Makinson, R.O. (Royal Botanic Gardens, Mrs Macquaries Road, Sydney, NSW 2000, Australia) 2002. Ranunculus meristus (Ranunculaceae), a new stoloniferous species from eastern Australia. Telopea 9(4): 809-812. Ranunculus meristus is described; it is widely distributed in intermittently wet habitats, mostly on heavy soils, in southern Queensland and inland New South Wales.
\end{abstract}

\section{Introduction}

An undescribed species of Ranunculus was included, as 'species A', in the Flora of New South Wales (Briggs \& Makinson 1990, 2000). It is now described so that it can be included in the treatment of Ranunculaceae for the Flora of Australia (volume 2). Following the late Hansjorg Eichler's life-long interest in Ranunculaceae, his draft manuscript is being completed for the Australian Biological Resources Study by Neville Walsh and Jeff Jeanes (Eichler, Jeanes and Walsh, in preparation).

Ranunculus meristus B.G. Briggs \& Makinson, sp. nov.

A R.undoso combinatione characterum sequentium distinguitur: divisiones laminae angustiores (0.5-2 mm latae); achenia minoria (praeter rostra c. 1.0-1.6 mm longa), cristis angustis transversalibus vel obliquis instructa; margines acheniorum haud vel leviter incrassatae.

Type: New South Wales: Central Western Slopes: Bow Creek, $12 \mathrm{~km}$ WSW of Merriwa on road to Mudgee, 32 ${ }^{\circ} 07^{\prime} 30^{\prime \prime}$ S, $150^{\circ} 15^{\prime}$ E, 17 Mar 1984, B.G. Briggs 7430 (holo NSW; iso $\mathrm{AD}, \mathrm{BRI}, \mathrm{CANB}, \mathrm{CHR}, \mathrm{HO}, \mathrm{K}, \mathrm{MEL}, \mathrm{MO})$.

Stoloniferous perennial, glabrous or sparsely pilose; stolons stout $1.5-3 \mathrm{~mm}$ diam., arching and rooting at nodes. Flowering stems sparingly or repeatedly cymosely branched, mostly 15-50 cm high. Leaf blades $2.5-9 \mathrm{~cm}$ diam., palmately divided into acute or blunt segments that are mostly numerous and linear or very narrowly oblong, $0.5-1.5 \mathrm{~mm}$ wide, but in some (juvenile?) plants the segments are fewer and broader to $3 \mathrm{~mm}$ wide; petiole $5-20 \mathrm{~cm}$ long. Receptacle pilose in the staminal zone and among the achenes. Sepals 5, spreading, lanceolate or obovate, cymbiform, sparsely or densely pilose abaxially. Petals 7-11, obovate or narrow-obovate, 7.5-12.5 mm long, 2.5-5.5 mm wide; nectary in a pocket formed by a lobe attached laterally for most of its length. Achenes 30-85, mostly 1.0-1.6 mm long (excluding beak), the lateral faces with narrow transverse or diagonal ridges, the margins not or slightly thickened. (Fig. 1).

The epithet is from the Greek meristos = divided, divisible, referring to the finely divided leaf laminae.

Distribution: occurs from Springsure in Queensland south to Cootamundra in New South Wales; most common on the Darling Downs, the New South Wales Northern Tablelands and Central Western Slopes but extending to the northern edge of the 


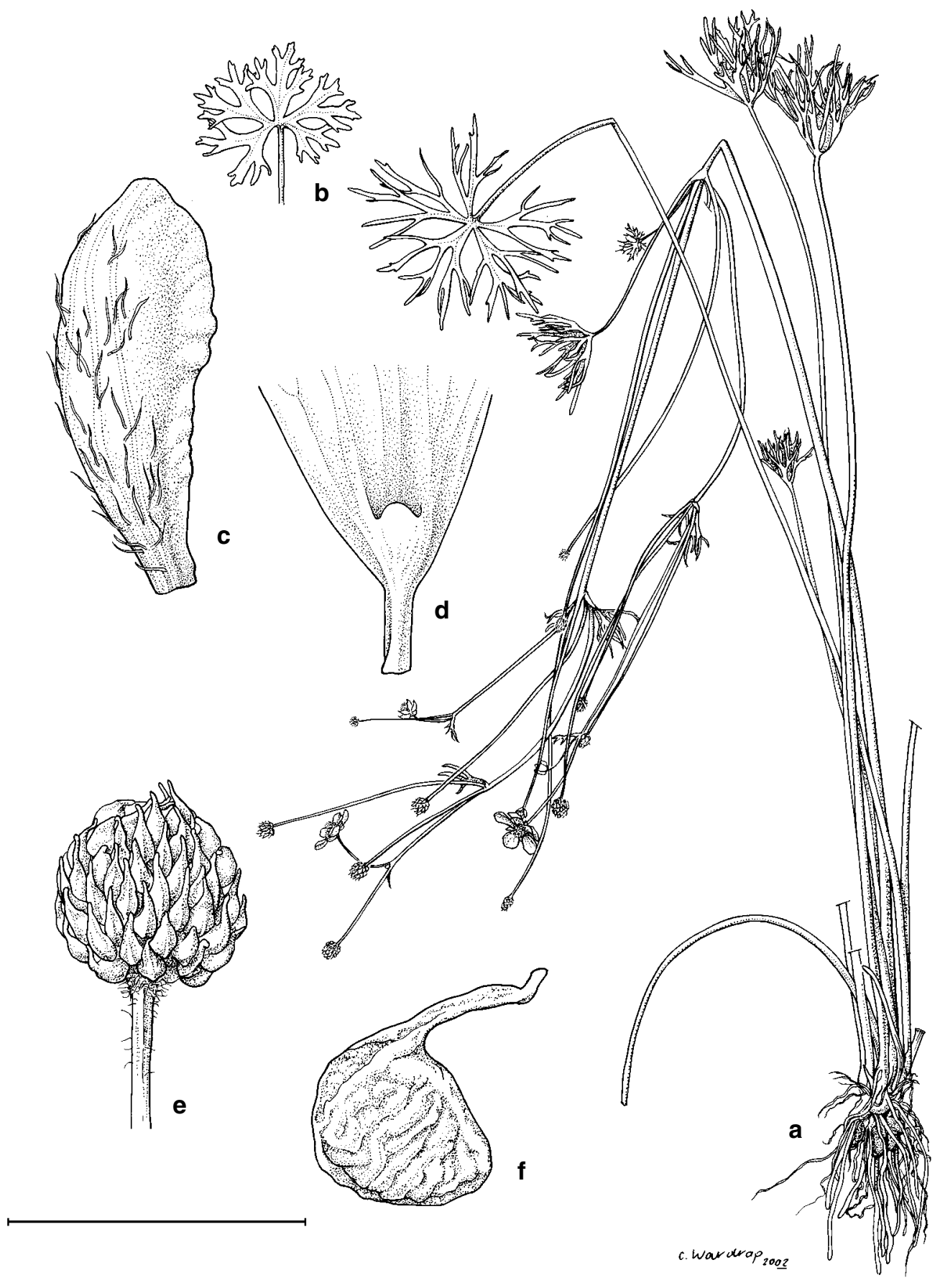

Fig. 1. Ranunculus meristus. a, habit. b, leaf showing broader segments. c, sepal, oblique abaxial view. $\mathbf{d}$, petal base with nectary lobe. e, head of achenes. $\mathbf{f}$, achene. $(\mathrm{a}, \mathrm{c}-\mathrm{f}$ from type collection; $b$ from Briggs 3457). Scale bar: $a, b=10 \mathrm{~cm} ; c, d=4 \mathrm{~mm} ; e=1 \mathrm{~cm} ; \mathrm{f}=2.4 \mathrm{~mm}$. 
South Western Slopes and the western edge of the North Coast and Central Coast. In intermittently wet swamps on heavy soils.

Conservation status: widespread and abundant in suitable habitats, not at risk.

Ranunculus meristus resembles $R$. undosus Melville and grows in similar habitats. It is distinguished from $R$. undosus by its narrower leaf segments and the smaller achenes which are not or slightly thickened at the margins and have narrow transverse or diagonal ridges. The leaf segments of $R$. undosus are mostly 2-8 mm wide and the achenes are 1.8-2.5 mm long (excluding the beak), with broad pale thickened margins (especially dorsally) and broad rounded ridges on the lateral faces. Much of the range of $R$. meristus lies to the north and east of that of $R$. undosus, but the distributions overlap extensively. Ranunculus meristus differs from $R$. inundatus $R$. Br. ex DC. in having larger leaves, pilose sepals, larger petals, achenes with distinct narrow ridges and the receptacle pilose among the achenes. Ranunculus inundatus has leaf laminae $1-3.5(-5) \mathrm{cm}$ diam., glabrous sepals, petals $4.5-7 \mathrm{~mm}$ long and 2-3 mm wide, lateral faces of achenes mostly smooth or irregularly undulate but rarely with transverse ridges, and the receptacle almost glabrous among the achenes (although pilose in the staminal zone). Ranunculus inundatus grows mostly in permanently wet sites, whereas the other two species are mostly in intermittently wet habitats. Specimens received from veterinary officers indicate that, as with many other Ranunculus species, R. meristus has been implicated in cases of poisoning of stock (e.g. cattle).

At the type locality it was noted by Briggs (and also at Bow Creek by Jacobs and Lapinpuro) that apparent clones varied considerably in the width of leaf segments. The broader leaf segments are mostly in non-flowering plants and may represent a juvenile leaf form. From the Central Western Slopes there are also several collections that may represent an extreme variant of $R$. meristus (not covered by the description above) or may be a distinct taxon. These have leaf laminae divided into only three, cuneate, lobed segments: Bow Creek, 12 Mar 1978, Jacobs 3339, Sainty 580 (NSW); Coolah, Nov 1964, Darville (NSW 77625); Coolaburragundy River S of Pandoras Pass, L.A.S. Johnson (NSW 53964); Scone District, Nov 1964, A.J. Boyle (NSW 77626); Lees Pinch crossing of Goulburn River, 16 Nov 1974, K.L. Wilson 704, L.A.S. Johnson $\mathcal{E}$ S. Jacobs (NSW); Cassilis, 29 Aug 1958, A. Busby (NSW 46006); Denman, Jan 1909, W. Heron (NSW 44991); Kerrabee (as Karabee), Nov 1912, L. Tindale (NSW 44989).

A flowering specimen purported to be from New South Wales South Coast (Batemans Bay, Jun 1906, J.L. Boorman [NSW 45025]) is probably wrongly labelled. The locality is remote from other collections and the species rarely flowers in winter.

Selected specimens examined: Queensland: Leichhardt: Springsure, Oct 1913, E. Jamis (BRI 1138). Maranoa: Dooloogarah, 130 km NW of Injune, 19 Apr 1999, R. Fensham 3701 (BRI, NSW). Wide Bay: Gympie, Jan 1907, F.H. Kenny (BRI 1090). Moreton: Yarraman, Dec 1956, W.T. Jones (BRI 10087); Heifer Ck, c. 2 miles [3 km] N of West Haldon, 2 Oct 1960, L. Pedley 696 (BRI). Darling Downs: summit bog, Bunya Mts, 24 Mar 1944, M.S. Clements 43923 (A-GH); Jimbour [as Jimbo], plains of the Condamine, L. Leichhardt (NSW 44979); Dalby to Chinchilla, 4 Sep 1978, T.D. Stanley \& S.T. Reynolds 7825 (BRI); Warrego Hwy, $10 \mathrm{~km} \mathrm{~W}$ of Dalby, 2 Oct 1975, K.A. Williams 75093 (BRI); 7 miles [11 km] W of Dalby, 3 Sep 1956, N.T. Burbidge (CANB 5458, NSW); Merritts Creek road, W of Hampton, 26 Jan 1995, A.R. Bean 8197 (BRI, NSW); Clifton, Kings Ck, 17 Mar 1971, S.R. Walsh 771 (BRI).

New South Wales: North Coast: Curricabark, NW of Gloucester, 4 Apr 1969, B.G. Briggs (NSW 124376); c. $1.5 \mathrm{~km} \mathrm{~W}$ of 'Myra' homestead, NW of Gloucester, 22 Sep 1968, D. Blaxell \& R. Coveny 577 (NSW). Central Coast: Colong Creek, S of Yerranderie, 5 Dec 1911, R.H. Cambage 3214 (NSW). Northern Tablelands: Glen Innes, Dec 1913, J.L. Boorman (NSW 45039), 8 Dec 1924, E. Cheel (NSW 45041); Tenterfield to Sandy Flat, Dec 1898, J.H. Maiden (NSW 45038); Blackfellows Gully, E of Walcha, 12 Jan 1958, N.C. Ford (NSW 45027); Tia to Walcha, Nov 1897, J.H. Maiden (NSW 45046). North Western Slopes: E of Woodsreef Mine, 27 Oct 1992, J.R. Hosking 606 (NSW, CANB, MEL, NE); 9 km S of Limbri, 4 Jan 1989, J.R. Hosking (NSW 218627); 15 km NW of Wandsworth on Tingha road, 26 Nov 1982, 
S. Jacobs \& L. Lapinpuro LL 18 (NSW). Central Western Slopes: 14 km N of Rylstone, 9 Nov 1989, W. Semple OR169 (NSW); Blandford, Oct 1922, C.L.O. Gorman (NSW 45045); c. $7.3 \mathrm{~km}$ SW from the Merriwa-Cassilis road towards Wollar, 7 Nov 1969, R. Coveny 2426, 2427 (NSW, K); Bow Creek, $10 \mathrm{~km}$ WSW of Merriwa, 14 Mar 1970, B.G. Briggs 3457 (NSW, BRI); Spring Creek, $10 \mathrm{~km}$ SW of Merriwa, 14 Mar 1970, B.G. Briggs 3458 (NSW, K). South Western Slopes: Harden, 7 Mar 1975, J. Kenison (NSW 517937); Barthong, Cootamundra district, 18 Dec 1975, J. Whiteley (NSW 517936).

\section{Acknowledgments}

We thank Neville Walsh and the late Dr Hansjorg Eichler and for valuable discussions of this species, Dr Tony Orchard for making available to us Dr Eichler's draft manuscript for the Flora of Australia, Catherine Wardrop for the illustration and Dr Peter Wilson for assistance with the Latin diagnosis.

\section{References}

Briggs, B.G. and Makinson, R.O. (1990, 2000) Ranunculaceae. Pp. 155-167 in Harden, G.J. (ed.), Flora of New South Wales, vol. 1: 164, Edn 1 (1990); Edn 2 (2000). (New South Wales University Press: Kensington).

Eichler, Hj., Jeanes, J.A. \& Walsh, N.G. (in prep.) Ranunculaceae. Flora of Australia Vol. 2 (ABRS/CSIRO Publishing: Melbourne).

Manuscript received 18 January 2002

Manuscript accepted 5 June 2002 